Poznańskie Studia Teologiczne 28(2014), s. 155-164.

doi: $10.14746 /$ pst.2014.28.10

Jarosław Moskałyk

Uniwersytet im. Adama Mickiewicza w Poznaniu

Wydział Teologiczny

\title{
Wiara jako synteza słuchania i widzenia według Lumen fidei
}

W drugiej części encykliki Lumen fidei papieża Franciszka został podjęty bardzo ważny aspekt rozważań o wierze pochodzącej ze słuchania i widzenia ${ }^{1}$. W tym głębokim związku biskup Rzymu dostrzega sens historycznego rozwoju wiary oraz ubogacenia ludzkiego istnienia we wszystkich jego wymiarach ${ }^{2}$. Niewątpliwie kategorie słuchania $\mathrm{i}$ wiedzenia mają całkiem pierwotne i bezpośrednie odniesienie do osobowej wiary człowieka oraz wspólnotowej wiary Kościoła. Na nich opiera się przede wszystkim związek i relacyjność słowa i jego odbiorcy. Dzięki nim powstaje dynamizm ludzkiego działania i rodzi się pragnienie nieustannego wstępowania w nową przestrzeń poznawczą wiary, a następnie uczynienia jej prawdziwym doświadczeniem w spotkaniu z Bogiem. Choć słuchanie $\mathrm{i}$ widzenie $\mathrm{z}$ natury swej przeznaczone są do spełnienia odrębnej i zarazem innej funkcji, to ich rola w stosunku do wiary jest na swój sposób zamienna i komplementarna. Ponadto indywidualne znaczenie obu przymiotów w perspektywie wiary zakłada ich zróżnicowaną interpretację teologiczną.

\section{Od słuchania i widzenia do słowa i światla}

Wiara osoby czerpie z głębokiego źródła przekazu wewnętrznego i zewnętrznego. $\mathrm{O}$ ile ten dar wewnętrzny stanowi nieogarnioną tajemnicę przenikania $\mathrm{z}$ góry ludzkiego rozumu, świadomości i ducha, o tyle dar zewnętrzny jawi się jako coś danego i dostępnego człowiekowi. Wśród takich darów są właśnie możliwość słuchania i widzenia, ale też uczestniczenia w słowie i świetle. Według papieża, skoro wiara jest słuchaniem i widzeniem, to przekazywana jest również jako słowo i światło $^{3}$. Jednak słowo musi być najpierw usłyszane a światło dostrzeżone, aby mogły stać się naszą własnością. Inaczej mówiąc, bez zdolności słyszenia i widzenia nie sposób oczekiwać otwarcia ani tym bardziej rozumienia słowa czy poznania światła.

\footnotetext{
${ }^{1}$ Franciszek, Lumen fidei, 29-31.

${ }^{2}$ Tamże, 6.

${ }^{3}$ Tamże, 37.
} 
Dlatego ten, kto należycie przyjmuje zadatek słuchania i widzenia, nigdy nie może przestać słyszeć głosu Boga ani utracić pragnienia widzenia Jego światła ${ }^{4}$. Zdaniem Paula Evdokimova, słowo wchodzi do historii, nie tylko mówi, lecz tworzy historię i wzywa ludzi do czynów, które widzialnie wyrażają ich ducha. Czas jest nieodłączny od przestrzeni i każde twórcze słowo kieruje się do słuchu i wzrokus.

Ponieważ egzystencja ludzka ma strukturę dialektyczną i dynamiczną, pozwala jej to znajdować się w nieustannym poszukiwaniu nowości, odrodzenia oraz dążeniu do nowej jakości bytowania. Dzieje się tak w znaczącym stopniu za pośrednictwem dialektycznego związku wrażliwości słuchowej na słowo oraz przyciagania wzrokowego światłem. Dlatego przyjęte ze słyszenia słowo staje się odpowiedzią, wyzwaniem i w ten sposób rozbrzmiewa z ogromną siła, angażując nie tylko jednostkę, ale i społeczność powszechną. Obecność słowa daje przekonanie o potrzebie wiary i ufności w jego niezmienny oraz nieprzemijający charakter. „To wam oznajmiamy, co było na początku, cośmy usłyszeli o Słowie życia, co ujrzeliśmy własnymi oczami, na co patrzyliśmy i czego dotykały nasze ręce - bo życie objawiło się. Myśmy je widzieli, o nim świadczymy" (1 J 1-3). Podobną rzecz należy oznajmić o świetle, w które wpatrując się, zbliżamy się do jasności Pańskiej, która odbija się jakby w zwierciadle. Odbicie tego światła zaś przenosi się z jednego oblicza na drugie, tak jak Mojżesz nosił w sobie odblask chwały Bożej po rozmowie z Nimº . „Bóg zabłysnął w naszych sercach, by olśnić nas jasnością poznania chwały Bożej na obliczu Chrystusa" (2 Kor 4,6).

Światło Jezusa, jak podkreśla papież, jaśnieje jak w zwierciadle na obliczach chrześcijan i tak się rozchodzi, i tak dociera do nas, abyśmy i my mieli udział w tym widzeniu i odzwierciedlali innym Jego światło ${ }^{7}$. W końcu światłem przeniknięte jest całe życie człowieka zarówno w sensie samodoskonalenia, jak i upadku. Ponadto ono przychodzi skądinąd i gdzie indziej prowadzi ludzi wyznających jego zasadę oddziaływania. Jednakże światło, ale także słowo, które czerpie swoją żywotność z widzenia i słyszenia, nie przestaje wzywać osoby ludzkiej do wiarygodnej akceptacji tej złożonej relacyjności. Na czym ma polegać ta właściwa afirmacja? Należy tu zwrócić uwagę przede wszystkim na następujące zjawisko, otóż światło i słowo jako dwie różne rzeczywistości, a zarazem stanowiące odmienną perspektywę spojrzenia na świat stworzony i niestworzony, nie przestają nigdy istnieć $\mathrm{w}$ oderwaniu od indywidualnego widzenia i słuchania. Zatem nie są one i nie mogą być oddzielone od źródła pierwotnego. Co więcej wskazują na zachodzącą między nimi zależność i skuteczne wzajemne dopełnienie. Tego zaś nie można lekceważyć w kontekście wiary osobowej.

\footnotetext{
${ }^{4}$ Por. J. Ratzinger, Na poczqtku Bóg stworzyt ... Cztery kazania o stworzeniu i upadku. Konsekwencje wiary w stworzenie, Karków 2006, s. 95-96.

${ }^{5}$ P. Evdokimov, Sztuka ikony. Teologia piękna, tłum. M. Żurowska, Warszawa 1999, s. 34-35.

${ }^{6}$ Franciszek, Lumen fidei, 37.

${ }^{7}$ Tamże, 37.
} 
Dopiero na gruncie wiary staje się możliwe uznanie podstaw tej niezwykłej relacyjności. Konsekwencją tego jest dojście do przekonania, że tylko uważne słuchanie rozwija tęsknotę za prawdziwym słowem bynajmniej nie dla zaspokojenia własnej ciekawości, ale choćby celem zmiany swego stosunku wobec słowa codziennego i - co najważniejsze - słowa objawionego. Natomiast umiejętność dostrzeżenia ludzkimi oczami tego, co istotnie się kryje w promieniach światła doczesnego, czyli wpierw jasności i ciepła, z zasady pobudza i daje odwagę ku odnalezieniu światła jeszcze innego oraz pozadoczesnego, tego, które jest niezrównane z tym aktualnie dostępnym i zwrócone całkowicie ku przyszłej pełni i nieograniczoności.

\section{Przeciwieństwo między słuchaniem a widzeniem}

W encyklice Lumen fidei czytamy, że w przeszłości słuchanie przeciwstawiano niekiedy widzeniu, a powodem tego była niejako kultura helleńska ${ }^{8}$. W niej bowiem, w przeciwieństwie do tradycji hebrajskiej uznającej wyższość słuchu nad wzrokiem, od początku przewyższał zmysł widzenia nad zmysłem słyszenia, a za nią też poszła cała tradycja zachodnia. Na tę kwestię niegdyś zwrócił uwage teolog protestancki Gerhard Kittel, twierdząc, że w tekstach mesjańskich formuła „słuchaj Izraelu” ustępuje miejsca formule „podnieś wzrok i zobacz”. W związku z tym niektórzy zwolennicy wschodniej teorii obrazu i światła, a następnie jego przewagi nad słowem i słuchem, chętnie powołują się na scenę z przemienienia, kiedy pośrodku między dwoma prorokami, Mojżeszem i Eliaszem, jawi się Pan (Mt 17,3), albo też jedno z błogosławieństw: „Błogosławieni czystego serca, albowiem oni Boga oglądać będą" (Mt 5,8). Głównym zadaniem próby oddzielenia, a nawet przeciwstawienia, dwóch całkiem różnych prerogatyw na drodze poznania i zgłębienia wiary człowieka jest wywołanie napięcia. Samo zjawisko wiary bowiem w rzeczywistości zakłada zróżnicowaną reakcję, niezrównany poziom percepcji i wielorakość środków pośrednich.

Forma takiego działania zatem nie wydaje się sprzeczna $\mathrm{z}$ podstawową intencją poszukiwania odpowiedniej metody służącej osiagnięciu zamierzonego celu. Można nawet rzec, że jest ona w pewnym sensie niezbędna, aby rozwijać wielostronne i niczym nieograniczone podejście do całego zjawiska wiary. $\mathrm{W}$ ten sposób również kształtuje się doktryna chrześcijańska, która dzięki swoim zróżnicowanym poglądom i koncepcjom tworzy bardziej otwartą postać w relacji do innych dyscyplin naukowych, a - co najistotniejsze - w odniesieniu do innych religii ${ }^{10}$. Niemniej jednak problem pojawia się wtedy, jeśli wewnątrz określonej

\footnotetext{
${ }^{8}$ Franciszek, Lumen fidei, 29.

${ }^{9}$ G. Kittel, Die Religiongeschichte und das Urchristentum, Tübingen 1932, s. 34.

${ }^{10}$ Por. J. Ratzinger, Wielość religii i jedno Przymierze, tłum. E. Pieciul, Poznań 2004, s. 55-58.
} 
struktury poznania religijnego dochodzi do sztucznego zderzania odmiennych wizji i priorytetów postrzegania. Będzie to dotyczyć między innymi kryterium słuchania i widzenia w relacji do wiary. Stąd w pełni zasadna i trafna intencja zawarta $\mathrm{w}$ encyklice, aby starać się nie szukać na siłę opozycji między słyszeniem i widzeniem, a wreszcie między słowem i światłem.

Jak bowiem zostało podkreślone, Stary Testament łączy obydwa rodzaje poznania, ponieważ słuchanie słowa Bożego łączy się z pragnieniem oglądania oblicza Boga. Dzięki temu stał się możliwy dialog z kulturą helleńską, dialog należący do istoty Pisma Świętego. Słuchanie wskazuje na osobiste powołanie i posłuszeństwo, a także na objawianie się prawdy w czasie; wzrok umożliwia pełny ogląd całej drogi i pozwala wpisać się w wielki Boży plan; bez tego oglądu dysponowalibyśmy jedynie odosobnionymi fragmentami nieznanej całości ${ }^{11}$. Związek między widzeniem i słuchaniem jako narzędziami poznania wiary jest bardzo jasno ukazany w Ewangelii św. Jana, według której wierzyć to słuchać i jednocześnie widzieć ${ }^{12}$. Słuchanie nakazuje naśladowanie, jak w przypadku pierwszych uczniów, którzy „usłyszeli, jak mówił, i poszli za Jezusem” (J 1,37). Jednak należy pamiętać o tym, że prawidłowo ugruntowana za pomocą uważnego słuchania wiara prowadzi także do głębszego widzenia (J 11,40). Dzięki temu zespoleniu, jak głosi encyklika, widzenie staje się pójściem za Chrystusem, a wiara jawi się jako droga widzenia, na której oczy przyzwyczajają się do spoglądania w głąb $b^{13}$. I tak, w poranek wielkanocny, od Jana, który gdy było jeszcze ciemno, przed pustym grobem „ujrzał i uwierzył” (J 20,8), przechodzimy do spojrzenia Marii Magdaleny, która już widzi Jezusa (por. J 20,14) i chce Go zatrzymać, ale zostaje zachęcona do kontemplowania Go na Jego drodze do Ojca ${ }^{14}$.

Niezachwianą więź między słuchaniem i widzeniem doskonale tłumaczy obecność ikony w systemie chrześcijańskiej kultury. Ikona właśnie jako uniwersalny tekst zasad wiary, który służy poznaniu prawdy, zakłada zawsze przekroczenie pewnego progu ludzkiej obojętności i niepewności. Te bowiem najczęściej są rezultatem zaniechania, jeśli chodzi o rozumienie ze słuchania i odczytywanie za pomocą widzenia. Zdaniem Jana Damasceńskiego, ikona nie proponuje prostych ani banalnych treści, lecz stara się odsłonić świat niewidzialny, trudny do zrozumienia, oddziałując najpierw na wzrok człowieka ${ }^{15}$. Dopiero reakcja i odpowiedź wzrokowa daje nadzieję na autentyczne spotkanie z nową rzeczywistością również na bazie słowa, które wyjaśnia i rozważa treść ikony, a zarazem uczy gotowości słuchowej.

\footnotetext{
${ }^{11}$ Franciszek, Lumen fidei, 29.

12 Tamże, 30 .

13 Tamże.

${ }^{14}$ Tamże.

${ }^{15}$ Por. I. Jazykowa, Świat ikony, thum. H. Paprocki, Warszawa 1998, s. 16.
} 
Ikona od początku była rozumiana jako zjawisko sakralne o znaczącym potencjale przybliżania do siebie różnych światów, ale także ludzi o zróżnicowanych poglądach na temat obecności pierwiastka Boskiego w tym świecie. Dlatego z czasem coraz częściej była traktowana jako wyjątkowy tekst, który wymaga odpowiedniego nawyku czytania po to zwłaszcza, aby móc jaśniej widzieć w niej niestworzone światło. Im lepszy odbiór nadprzyrodzonego światła ikony, tym pełniejsze uznanie związku przedstawienia z widzeniem. Dla człowieka współczesnego, zwłaszcza wychowanego poza tradycją chrześcijańską, język ikony jest nazbyt trudny, ponieważ na jego myślenie i percepcję estetyczną ogromny wpływ wywiera realizm praktyczny oraz iluzoryczny obraz filmowy. Ikona natomiast jest zwrócona ku nowemu niebu i nowej ziemi i dlatego zawsze dąży do zasadniczej inności, do przedstawienia inności przemienionego świata ${ }^{16}$.

Spotkanie z ikoną każdorazowo umożliwia wstappienie w nową przestrzeń poznania wiary, gdzie według św. Augustyna realizuje się filozofia światła, która przejmuje właściwą słowu wzajemność i dopuszcza wolność patrzenia w kierunku światła. I tak jak na słowo pada wolna odpowiedź, podobnie światło znajduje jako odpowiedź obraz, który je odbija ${ }^{17}$. W związku z tym nie ma podstaw, aby przeciwstawiać słowo światłu, a słuchanie widzeniu, gdyż otwarty stosunek wobec obu tych płaszczyzn zależy od wewnętrznego nastawienia osoby oraz pokonania przez nią tendencji do ich przeciwstawiania w obliczu wiary. Światło wiary jest światłem wcielonym, mającym źródło w świetlanym życiu Jezusa. Oświeca ono również materię, a - co najważniejsze - ludzkie ciało i duszę, ufa w jej ład, wie, że w niej otwiera się coraz szersza droga harmonii i zrozumienia ${ }^{18}$.

\section{Wspólny punkt odniesienia wobec słuchania i widzenia}

Dla wiary chrześcijańskiej najwyższym punktem odniesienia jest Jezus Chrystus, o którym nie tylko wiemy, ale którego możemy również widzieć i słyszeć. On jest Słowem, które stało się ciałem, którego chwałę oglądaliśmy (por. J 1,14). Oznacza to, jak głosi encyklika Lumen fidei, że poznanie wiary nie zachęca nas do oglądania czysto wewnętrznej prawdy. Prawda, jaką przed nami odsłania wiara, jest skupiona na spotkaniu z Chrystusem, na kontemplacji Jego życia, na dostrzeganiu Jego obecności ${ }^{19}$. Prawda, którą wiara pojmuje, jest bowiem objawieniem się Ojca w Synu, w Jego ciele oraz w Jego ziemskich czynach; tę prawdę można określić jako, ,jaśniejące życie” Jezusa ${ }^{20}$. Ponieważ Bóg stał się widzialny w ciele i zarazem zechciał zbawić człowieka za pośrednictwem materii, odtąd

\footnotetext{
${ }^{16}$ Tamże, s. 22.

${ }^{17}$ Franciszek, Lumen fidei, 33.

${ }^{18}$ Tamże, 34.

19 Tamże, 30.

${ }^{20}$ Tamże.
} 
również materia niejako na nowo została podniesiona do poziomu godnego chwały Boga ${ }^{21}$.

We współczesnym świecie w widoczny sposób wzrasta znaczenie materii, zaś człowiek wykazuje coraz większą skłonność do jej jednostronnego wykorzystania. Jest to między innymi efekt zatracenia zdrowego podejścia do wartości pozamaterialnych. Jeśli odwołamy się do bardziej bezpośredniej analogii i odniesiemy się do słuchania i widzenia, możemy powiedzieć, że obecnie ludzkość w niewiarygodnym stopniu zatraciła poczucie ich autentycznego przeznaczenia. Tymczasem tego rodzaju zwykle świadome zaniechanie prowadzi do jeszcze głębszego spłycenia i uproszczenia pierwiastka materii. Zmiana preferencji w podejściu, a zwłaszcza traktowanie sfery materialnej jako nadrzędnej w życiu człowieka burzy jego prawdziwy system wartości. Wówczas materia przestaje wyrażać obecność Boga, a jednocześnie nie tworzy już z Nim relacji. Taka postawa jest szczególnie zwodnicza w przypadku wiary osobowej, która - zdaniem Oliviera Clémenta - wymaga pełnego zaufania ze względu na swoją autentyczność. Wiara, która powinna karmić także nasze doświadczenie, nie może być oderwana od całościowego przeżycia materialno-duchowego. Z kolei najpełniejszy sens doświadczenia duchowego łączy się z przeżyciem sakramentalnym i liturgicznym ${ }^{22}$.

Równie istotną rolę, szczególnie w tradycji wschodniej, odgrywa symbolika ikonograficzna. Człowiek poszukujący prawdy oraz upodmiotowienia w wierze dostrzega w ikonie most łączący nie tylko dwa światy - widzialny i niewidzialny, ale także świat kultury i świat objawienia. Ikona pełni niezrównaną funkcję katechetyczną, ponieważ za pomocą języka symboliczno-obrazowego umożliwia poznanie sensu słowa Bożego poprzez obraz. Jednocześnie wpływa na wyobraźnię wzrokową i słuchową, przekonując niejednokrotnie bardziej aniżeli treści dogmatyczne czy rutynowe pouczenia religijne. Poza tym ludziom poważnie traktującym swój związek z Kościołem pomaga w pogłębieniu modlitwy i życia duchowego. Kontakt $\mathrm{z}$ ikoną pomaga aktualizować i umacniać zarówno wiarę jednostkową, jak i wspólnotową. Natomiast przekroczenie jej warstwy materialnej powoduje refleksyjność, dialogiczność i ożywienie wiary człowieka.

Ponieważ wspólnym punktem odniesienia dla wszystkich chrześcijan jest światło wiary w Jezusa, dlatego jesteśmy wezwani do zgłębiania jego mocy i badania coraz bardziej rozjaśnianych przez samą wiarę horyzontów, aby, jak wyjaśnia encyklika, lepiej poznać to, co kochamy. Prawidłowa wiara skłania rozum do otwarcia się na światło pochodzące od Boga, aby kierując się miłością do prawdy, mógł on poznawać Boga w głębszy sposób ${ }^{23}$. Chrześcijańskie wyznanie wiary w Jezusa, jedynego Zbawiciela, stwierdza, że całe światło Boże skupia się w Nim, w Jego ,jaśniejącym życiu”, w którym odsłania się początek i koniec dziejów. Nie ma żad-

\footnotetext{
${ }^{21}$ Benedykt XVI, Deus caritas est, nr 9.

${ }^{22}$ Por. O. Clément, Biesiedy s patriarchom Afinagorom, Bruxelles 1993, s. 16-17.

${ }^{23}$ Franciszek, Lumen fidei, 36.
} 
nego ludzkiego doświadczenia, żadnej drogi człowieka do Boga, której światło nie mogłoby przyjąć, oświecić i oczyścić. Im bardziej chrześcijanin zagłębia się w krąg otwarty przez Chrystusowe światło, tym bardziej staje się zdolny zrozumieć każdego człowieka w drodze do Boga i towarzyszyć $\mathrm{mu}^{24}$.

Czy można tego nie słyszeć i nie widzieć? $\mathrm{Z}$ pewnością można $\mathrm{i}$ wiele jest na to przykładów. W każdym z nich chodzi jednak o odrzucenie albo zatracenie jednego z istotnych fundamentów ludzkiego wzrostu i samodoskonalenia, które się dokonują za pośrednictwem daru słuchu i widzenia. Brak akceptacji obrazu objawionego nam jeden raz w Osobie Chrystusa, który oświeca nasze życie i odkrywa możliwość przywrócenia obrazu Bożego w nas oraz przemienienia całego świata, sprawia, że nasza codzienność jest samotna i jałowa. Skoro celem stworzenia człowieka na obraz Boży było wcielenie, to w nim zawarty został również wymóg najwyższej łączności między Bogiem i człowiekiem ${ }^{25}$. Ona zaś może być realizowana pod warunkiem uruchomienia receptorów słuchu i wzroku, które prowadzą do autentycznego poznania istoty partnerstwa i rozwoju osobowej wiary, która w ostateczności może być pojęta jako akt narodzenia człowieka w Bogu, dokonany dzięki impulsowi syntezy słuchania i widzenia.

Do interesującej konkluzji na temat ludzkiego stosunku do urzeczywistnienia piękna i miłości w świecie doszedł Fiodor Dostojewski w swoich rozważaniach filozoficznych. Jego zdaniem, podstawowy problem z oddaniem im należnej czci polega na tym, że człowiek, zanim jeszcze zrozumiał i poznał piękno i miłość, już je sprofanował ${ }^{26}$. Tę krytyczną ocenę postawy ludzkiej można przenieść także na kategorię słuchu i wzroku, które jeśli zostają niewłaściwie wykorzystane, prowadzą jednostkę do wykolejenia bądź nihilizacji. Ma to szczególnie przykre konsekwencje dla wiary człowieka, która łączy się zarówno z wewnętrznym powołaniem, jak i zewnętrznym motywem pochodzącym ze słuchania i widzenia. Gdy ów zewnętrzny instynkt z jakichś powodów będzie zniweczony, to siłą rzeczy dojdzie też do zagłuszenia głosu wewnętrznego. Wtedy poddanie ateizacji czy nihilizacji wydaje się procesem postępowym i nieodwracalnym. Jednak, zdaniem Dostojewskiego, nawet tak daleko idące samozatracenie człowieka nie powoduje całkowitej utraty wrodzonej intuicji otwarcia na piękno i wiarę. Dlatego nihiliści mają oczy nieustannie zwrócone na piękno i je kochają, z kolei ateiści może jeszcze bardziej niż inni potrzebują bóstwa i natychmiast je tworzą, by oddawać mu cześćc 27 .

Prawda wiary warunkuje i gromadzi w sobie wartości wewnętrzne, jak świadomość i intuicję, ale także walory etyczne i estetyczne. Te drugie w znaczącym stopniu są uzależnione od stopnia rozumienia daru słowa i światła, które prowa-

\footnotetext{
${ }^{24}$ Tamże, 35.

${ }^{25}$ Por. P. Evdokomov, Sztuka ikony. Teologia piękna, dz. cyt., s. 47.

${ }^{26}$ Tamże, s. 41.

${ }^{27}$ Tamże.
} 
dzą zawsze do głębi i nieograniczoności, a w sensie religijnym do nieskończoności. Gdyby istoty ludzkie pozbawić tego, uważa filozof rosyjski, co jest nieskończenie wielkie, wówczas straciłyby ochotę do życia i umarłyby z rozpaczy. Niezmierzone i nieskończone jest tak samo potrzebne człowiekowi, jak ta mała planeta, po której się porusza ${ }^{28}$.

\section{Zwrócenie ku światlu przyszlości}

Encyklika głosi, że wiara nie jest tylko indywidualnym wyborem dokonującym się we wnętrzu wierzącego, nie jest odizolowaną relacją między ,ja” wiernego i „Ty” Boga, między autonomicznym podmiotem i Bogiem ${ }^{29}$. A ponieważ słuchanie i widzenie otwiera człowieka na wiarę, to jest to też ruch ku perspektywie przyszłej i nieograniczonej. Ludzka zdolność słuchania i widzenia nigdy nie zatrzymuje się i nie jest przywiązana wyłącznie do pierwiastka doczesnego i materialnego. Decyduje o tym objawiająca funkcja, która należy do człowieczeństwa Chrystusa, a która staje się zarazem prawdą każdej ludzkiej istoty ${ }^{30}$. Stąd, kiedy chrześcijanie wyznają wiarę w zbawienie, nie myślą jedynie o wyzwoleniu z doczesnego upadku, ale swoim słuchem i wzrokiem starają się każdorazowo zbliżać ku idei pełnej przemiany w życiu przyszłym i ku uczestnictwu w Bożym pięknie. W rozumieniu Wschodu być w stanie przebóstwienia to kontemplować światło niestworzone i pozwalać się mu przenikać. Choć Bóg pozostaje ukryty w swojej istocie, to nie oddalił się całkowicie od tego świata i człowieka, tylko swoimi objawieniami przyciaga ich do siebie.

Człowiek, wyznając wiarę w zbawienie słowem, jednocześnie potwierdza ją działaniem, które jest wyrazem nowego postrzegania przyszłego światła. Dlatego już teraz wpatrujemy się z pokorą i utęsknieniem w światłość paruzji. Niemniej jednak nie można powiedzieć, że wychodzenie naprzeciw światłu eschatologicznemu przychodzi nam z łatwością i bez oporu. Współczesny człowiek, korzystając w sposób szczególny z prawa do wolności, coraz ostrzej odczuwa wewnętrzne rozdwojenie i rozbicie. Nawet wtedy, gdy budzi się w nim potrzeba wiary, nierzadko ulega pokusie ucieczki od niej, ponieważ nie żyje on w zgodzie z samym sobą, $\mathrm{z}$ otoczeniem, z Bogiem. Tymczasem im bardziej człowiek oddala się od Boga i wiary w Niego, tym mocniej wpycha siebie w ciemność swego bytowania. Aktualny postęp cywilizacyjny i kulturowy, niestety, często powoduje zawężenie lub dezintegrację spojrzenia na tajemnicę osobowego istnienia człowieka ${ }^{31}$.

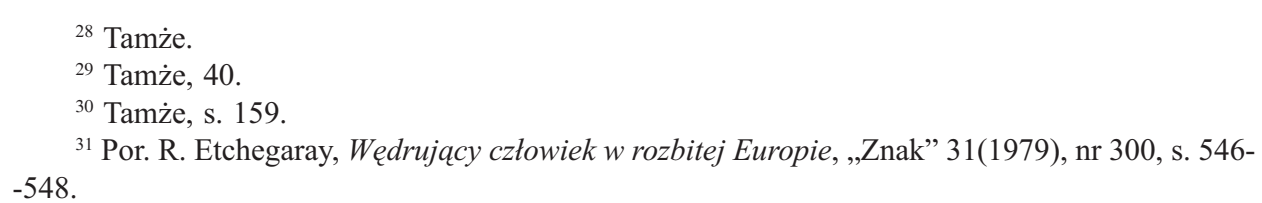


Życie chrześcijańskie wymaga zawsze czegoś więcej niż tylko pochylenia się nad ludzkim losem doczesnym, ponieważ wyraża wiarę, zjednoczenie, poznanie oraz przemianę na obraz i podobieństwo Boże. Z nim łączy się także właściwa łaska, która może przemieniać duszę człowieka. Wprawdzie nie wszyscy przemieniają się w ten sam sposób i nie wszyscy są w stanie osiagać coraz większy stopień chwały, choćby z powodu utraty kontaktu ze światłością nieprzemijająca albo z powodu jakiejś bezradności w docieraniu do prawdy nieskończonej. Jednakże, zdaniem Symeona Nowego Teologa, „dla tych, którzy już kiedyś stali się dziećmi światłości i synami dnia przyszłego, i którzy zawsze postępują w światłości, dzień Pański nigdy nie nadejdzie, gdyż są oni nieustannie z Bogiem i w Bogu. Ten dzień Pański objawi się nagle tym, którzy pozostają w mrokach namiętności i żyją według tego wieku, przywiązani do dóbr przemijających" ${ }^{32}$.

Wiara w przyszłe spełnienie dziejów kieruje wzrok ku światłu przyszłości, a równocześnie oddala wątpliwość dotyczącą możliwości spotkania już teraz zmartwychwstałego Chrystusa. Oznacza to, że nadzieja na chwalebne przyjście Pana nie ogranicza się do cząstkowego spełnienia w teraźniejszości i nie odsuwa go na czas „wiecznie” odległy. Wiara w paruzję musi ustawicznie wpływać na ludzkie pozytywne nastawienie do życia i doświadczenia dziejów. Współczesna teologia chrześcijańska podchodzi do wydarzenia paruzji z większym entuzjazmem, niż to czyniono wcześniej. Teraz zwraca się uwagę na to, że eschatyczne spełnienie dziejów jest długim procesem dokonującym się przez całą historię ludzkości ${ }^{33}$. Towarzyszy też jemu ciągle światłość niebieska, dzięki której jest jeszcze bardziej dostępne dla rodzaju ludzkiego. Jest to proces nieodwracalny, którego początek, środek i punkt szczytowy stanowi zmartwychwstały Chrystus. Kto wierzy, że On „powróci”, wyraża tym samym wiarę, że wszyscy ludzie dochodzą do Niego jako do swego Sędziego i Zbawcy ${ }^{34}$. Dlatego, jak twierdził Orygenes, kres człowieka będzie jednocześnie wkroczeniem w światło Prawdy. Wówczas dopiero znikną wszelkie pozory i fikcje, a zatryumfuje prawda nieskończona. Wtedy niewątpliwie można będzie pojąć, że Bóg był zawsze blisko, choć Jego światło często znikało przed naszymi oczami ${ }^{35}$.

Obecnie jednak wiara pokazuje, jak ważne jest jej przyjęcie za pośrednictwem słuchania i widzenia, dzięki czemu rozwija się także dynamika relacji wobec światła przyszłego. Ona pozwala, jak podkreśla papież w swej encyklice, zrozumieć architekturę relacji ludzkich, ponieważ dostrzega ich głęboki fundament i ostateczne przeznaczenie w Bogu i Jego miłości ${ }^{36}$. W jedności z wiarą

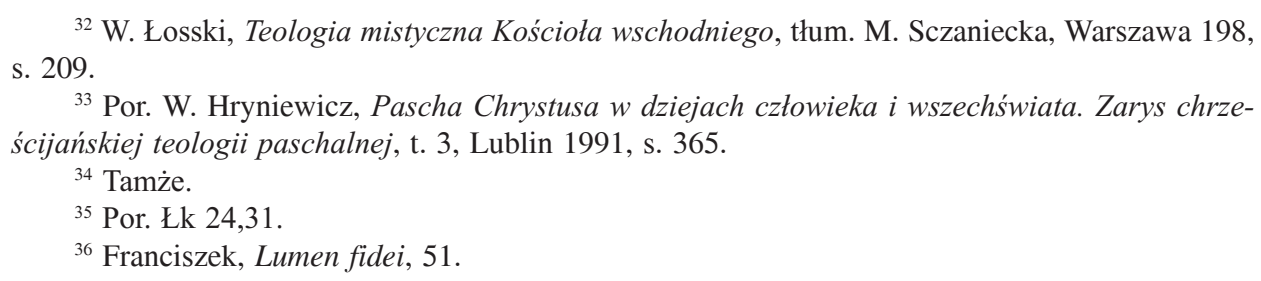

${ }^{32}$ W. Łosski, Teologia mistyczna Kościoła wschodniego, thum. M. Sczaniecka, Warszawa 198,

${ }^{33}$ Por. W. Hryniewicz, Pascha Chrystusa w dziejach człowieka i wszechświata. Zarys chrześcijańskiej teologii paschalnej, t. 3, Lublin 1991, s. 365.

${ }^{34}$ Tamże.

${ }^{35}$ Por. Łk 24,31.

${ }^{36}$ Franciszek, Lumen fidei, 51. 
i miłością nadzieja kieruje nas ku pewnej przyszłości, która wpisuje się w perspektywę inną niż iluzoryczne propozycje bożków tego świata, a która daje nam nowy zapał i nową siłę do codziennego życia ${ }^{37}$. Widzenie Boga w przyszłym świecie czyni człowieka nieśmiertelnym, a zarazem przysposabia do poznania Jego nieskończoności. Jeśli widzenie Ojca zaczyna się już na tej ziemi, to w przyszłym wieku stanie się ono jedynie spełnieniem nadziei dla sprawiedliwych.

$* * *$

Papież Franciszek w swojej encyklice Lumen fidei przypomniał bardzo istotną prawdę o potrzebie rozwoju całościowej świadomości religijnej dzięki wrodzonym zmysłom człowieka. Jednocześnie wskazał na ich rolę pomocniczą i dopełniającą w życiowym wyborze osoby, a zwłaszcza gdy chodzi o ufność i wierność Bogu. Perspektywę percepcji czegoś więcej poza obiektem dostrzegalnym materialnie otwiera $\mathrm{w}$ tym przypadku przede wszystkim właściwa postawa względem przymiotów słuchania i widzenia. Umożliwia ona zbliżenie do prawdziwej rzeczywistości nadprzyrodzonej, a zarazem uwalnia od jednostronnego przywiązania do wartości przemijających. Dar słuchania i widzenia wreszcie w jedyny i niepowtarzalny sposób aktywnie wzbogaca wnętrze jednostki ludzkiej obecnością i działaniem Boga.

Faith as the Synthesis of Listening and Seeing according to Lumen fidei

\section{Summary}

Pope Francis in his encyclical reminded us that Lumen fidei contains abundant material truth about the need of the development of a comprehensive religious awareness based on man's inborn senses. Simultaneously he pointed at their grounding and fulfillment in a person's practical choices, particularly those pertaining to confidence in and faithfulness to God. Here actual exercise of the attributes of listening and seeing opens the prospect of the perception of something more besides the materially discernible object. This creates the possibility of bringing closer to view the supernatural reality, and at the same time frees a person from a unilateral attachment to transient values. Finally, the gift of listening and seeing performs the only and unique function of actively enriching the inner life of the individual human with the presence and action of God.

\section{Keywords}

Pope Francis, Lumen fidei, listening, vision, word, light

\section{Stowa kluczowe}

papież Franciszek, Lumen fidei, słuchanie, widzenie, słowo, światło

\footnotetext{
${ }^{37}$ Tamże, 57.
} 